\title{
Behavior and postharvest evaluation criteria of Vriesea incurvata Gaudich. (Bromeliaceae) floral scapes ${ }^{(1)}$
}

\author{
EDWIN PULIDO(2)* ${ }^{(2 R A N C I N E ~ L O R E N A ~ C U Q U E L ~}{ }^{(2)}$, RAQUEL REJANE BONATO NEGRELLE $^{(2)}$
}

\begin{abstract}
Genus Vriesea of the Bromeliaceae family are highly appreciated to use as ornamental plant due to their floral morphological characteristics, color and the beauty of inflorescences. $V$. incurvata has been commercialized as a potted ornamental plant. The morphological features of its floral scape may also indicate it for use as a cut flower. However, there are no information available to use of this bromeliad as a cut flower. The aim of this study was to determine quantitative and qualitative criteria in order to evaluate the postharvest behavior of $V$. incurvata floral scapes. It was observed that $V$. incurvata floral scapes has great potential to use as cut flower, which has an average of vase-life of $14.9 \pm 1.5$ days. Quantitative and qualitative characteristics such as color $\left(\mathrm{L}^{*}, \mathrm{C}^{*}\right.$, $\mathrm{H}^{\circ}$ ), brightness, turgidity, stiffness, presence of injuries, relative fresh weight, water uptake and loss can be indicated as postharvest evaluation criteria of $V$. incurvata floral scapes.
\end{abstract}

Keywords: bromeliads, cut flowers, ornamental plant, senescence, vase-life.

\section{RESUMO}

Comportamento e critérios de avaliação pós-colheita de escapos florais de Vriesea incurvata Gaudich. (Bromeliaceae) O gênero Vriesea da família Bromeliaceae é altamente apreciado por seu uso como planta ornamental devido a suas características morfológicas florais, colorido e beleza das inflorescências. A comercialização de $V$. incurvata é como planta ornamental de vaso. As características morfológicas de seu escapo floral podem também indicá-la para uso como flor de corte. Contudo, não há informações disponíveis sobre o uso desta bromélia como flor de corte. O objetivo deste estudo foi determinar critérios quantitativos e qualitativos para avaliar o comportamento pós-colheita de escapos florais de $V$. incurvata. Observou-se que os escapos florais de $V$. incurvata apresentam grande potencial como flor de corte, alcançando uma vida de vaso média de 14,9 $\pm 1,5$ dias. As características quantitativas e qualitativas como cor $\left(\mathrm{L}^{*}, \mathrm{C}^{*}, \mathrm{H}^{\circ}\right)$, brilho, turgescência, rigidez, presença de injurias, massa fresca relativa, absorção e perda de água, podem ser indicados como critérios de avalição na pós-colheita de escapos florais de V. incurvata.

Palavras-chave: bromélias, flores de corte, planta ornamental, senescência, vida de vaso.

\section{INTRODUCTION}

Vriesea is a genus of bromeliads having 188 species (SMITH and TILL, 1998). These species have dispersion centers in the regions of South America, Central America and Caribbean. Vriesea incurvata Gaudich is native species of Brazilian Atlantic Rainforest. This species is epiphyte with green, smooth and without spines on the leaves, arranged in the form of rosettes and with red inflorescences (REITZ, 1983; MARTINELLI et al., 2008).

The prospection of new ornamental plants, from native species, represents a great potential of production and commercialization (HEIDEN et al., 2006). In this sense, $V$. incurvata has great potential due to their strong ornamental and landscape appeal. On the Paraná Coast Brazil, $V$. incurvata is considered as one of the ten most identified and commercialized bromeliads (NEGRELLE and ANACLETO, 2012). This bromeliad has been commercialized basically as a potted plant. However, having their aesthetic characteristics of inflorescence, it can also be considered a cut flower.
According to Junqueira and Peetz (2011), the cut flowers represent the greatest potential of export growth of national flower market adding high quality and competitive products in the international market.

Flower market is characterized by the frequent launching of new ornamental products, requiring additional attributes which can compete with products already established as rose, carnation, and Alstroemeria. Among the prerequisites for a plant to be considered suitable for commercialization as cut flower, the important characters are postharvest longevity and aesthetic characteristics (VABRIT, 2002; RAFDI et al., 2014).

Postharvest longevity as a business attribute determines market flexibility at any time. Vase-life of cut flowers is related to physio-chemical processes that affect the senescence, influenced by the loss of fresh weight and water inside the plant. (ALAEY et al., 2011). Aesthetic characteristics determine the products commercial perception, and morphological measures such as plant or organ size, number of flowers, leaves and flowers colors, etc., can be used as deciding factor to use as cut flower (BOUMAZA et al., 2009). 
However, there are numerous prerequisites or postharvest evaluation criteria and depending on the inherent characteristics of each species, these can influence behavior and senescence (RANI and SINGH, 2014).

A tool to measure the postharvest evaluation criteria in cut flowers is the use of grade scale. These scales allow the reduction of subjectivity of postharvest estimates, providing relevant information of the product in order to improve its quality (BOUMAZA et al., 2009).

For species of $V$. incurvata there are no related studies on the use of this plant as cut flower, the evaluation criteria, nor the postharvest behavior of floral scapes. In this context, the present study was undertaken to determine quantitative and qualitative criteria to evaluate the postharvest behavior of $V$. incurvata floral scapes, in order to contribute to the expansion of the use of this species as cut flower.

\section{MATERIAL AND METHODS}

\section{Plant material place and collection}

$V$. incurvata floral scapes of similar maturity (flowers with bracts: closed and turgid, shiny, firm and with orange color and red-orange margins) were collected in remaining of Atlantic Rainforest (25 $48^{\prime} \mathrm{S}$ and $48^{\circ} 55^{\prime} \mathrm{W}$, altitude 393 $\mathrm{m}$, in Guaratuba, Paraná, Brazil). The predominant climate of the region where the floral scapes were collected is tropical wet with no dry season and frost-free, with average temperature in the coldest month is of $18{ }^{\circ} \mathrm{C}$ - KöppenGeiger classification (RUBEL and KOTTEK, 2010). After harvesting, the floral scapes were kept in covered plastic boxes, protected with dry paper and transported to the laboratory.

\section{Plant material preparation and conduction}

Thirty floral scapes were cut in the basal part in bevel and they were standardized in $40 \mathrm{~cm}$ length. Basal leaves from the floral scapes were removed manually and floral scapes with defects or injuries resulting from transportation were discarded.

Floral scapes were weighed and labeled individually. Subsequently, each floral scape was placed in a vase $(1 \mathrm{~L}$ of capacity, $21 \mathrm{~cm} \mathrm{x} 8 \mathrm{~cm}$ ) with $200 \mathrm{~mL}$ of distilled water. The top of the vase was packed with plastic film leaving a central perforation for the floral scape exit. Vases were kept indoors (postharvest room) with a temperature of 20 $\pm 2{ }^{\circ} \mathrm{C}$, relative humidity of $80 \pm 3 \%$ and luminosity of 400-450 lux.

\section{Evaluation scale development}

The evaluation development of $V$. incurvata floral scapes was defined based on the most relevant qualitative characteristics in the commercial field of ornamental plants according to the VBN (Vereniging van Bloemenveillingen in Nederland), Veiling Holambra ${ }^{\circledR}$ and Royal Flora Holland $^{\circledR}$ ). Sensory evaluation was performed daily by three professionals previously trained in the postharvest quality control of cut flowers, during 28 days of observation period.
Postharvest evaluation criteria of floral scapes were measured through the assignment of grades, according to the visual characterization of senescence symptoms. The grouping was carried out based on the principles of easy visual identification and applicability in the scientific environment.

\section{Evaluation of postharvest behavior}

Floral scapes of $V$. incurvata were submitted to postharvest behavior evaluation, from the identification of quantitative and qualitative criteria. In order to validate the proposed evaluation scale, the same number of floral scapes $(n=30)$ were collected. The evaluations were carried out weekly by six new professionals previously trained in postharvest quality control of cut flowers during 28 days. Additionally, during this same time, the vase-life, relative fresh weight, water uptake and loss, and colorimetry of floral scapes were monitored.

The average vase-life of floral scapes was determined by the number of days from placing in the vase day to the appearance of senescence acute symptoms, such as presence of darkening, inflorescence abscission, inflorescence wilting, and tipping the scapes. Vase-life was recorded daily by visual observation of floral scapes.

Relative fresh weight of floral scapes was calculated using the formula RFW $(\%)=\left(\mathrm{FW}_{\mathrm{t}} / \mathrm{FW}_{\mathrm{t}=1}\right) \times 100$; where $\mathrm{FW}_{\mathrm{t}}$ is the fresh weight of scape $(\mathrm{g})$ at $\mathrm{t}: 7,14,21$ and 28 days and $\mathrm{FW}_{\mathrm{t}=1}$ : is the fresh weight of this scape $(\mathrm{g})$ of $\mathrm{t}: 1$ day (HE et al., 2006). Weekly, floral scapes were removed from vases and weighed in order to evaluate fresh weight.

Water uptake (WU) and water loss (WL) of floral scapes were calculated using the following formulas: a) WU (g scape $^{-1}$ day $\left.^{-1}\right)=\left(\mathrm{S}_{\mathrm{t}-1}-\mathrm{S}_{\mathrm{t}}\right)$; where $\mathrm{S}_{\mathrm{t}}$ is the weight of distilled water (g) at t: 7, 14, 21 and 28 days and $\mathrm{S}_{\mathrm{t}-1}$ is the weight of distilled water $(\mathrm{g})$ from the previous day (HE et al., 2006). b) WL $\left(\mathrm{g} \mathrm{scape}^{-1}\right.$ day $\left.^{-1}\right)=\left(\mathrm{C}_{\mathrm{t}-1}-\mathrm{C}_{\mathrm{t}}\right)$; where $\mathrm{C}_{\mathrm{t}}$ is the sum of scapes weights and vase $(\mathrm{g})$ at $\mathrm{t}: 7,14,21$ and 28 days and $\mathrm{C}_{\mathrm{t}-1}$ is the sum of scapes weights and vase $(\mathrm{g})$ from the previous day (HE et al., 2006). The water uptake and loss from the floral scapes were weekly recorded.

Colorimetry was measured in chromaticity $\left(C^{*}\right)$, hue $\left(\mathrm{H}^{\circ}\right)$ and luminosity $\left(\mathrm{L}^{*}\right)$ of the bracts color and recorded using the colorimeter (Konica Minolta, CR-400 ${ }^{\circledR}$ ). Readings were performed in the floral scapes, touching the colorimeter sensor to the surface of the base pointer (closed bracts of the inflorescence). Weekly, the values of $L^{*}(100=$ white; $0=$ black $), \mathrm{a}^{*}\left(\right.$ positive $=\operatorname{red}^{0^{\circ}} ;$ negative $=$ green $\left.^{180^{\circ}}\right)$ and $\mathrm{b}^{*}$ (positive $=$ yellow $^{90^{\circ}}$; negative $=$ blue $^{270^{\circ}}$ ) were recorded. Then the chromaticity formulas were applied, $\mathrm{C}^{*}$ $=\left[\left(a^{*}\right)^{2}+\left(b^{*}\right)^{2}\right]^{1 / 2}$ and Hue angle, $\mathrm{H}^{\circ}=\tan ^{-1}\left(b^{*} / a^{*}\right)$.

\section{RESULTS AND DISCUSSION}

Vase-life is an evaluation parameter used to determine postharvest longevity of cut flowers. According to Yamada et al. (2003), the increase of vase-life is the main goal researched in cut flowers. Results of these studies showed that $V$. incurvata floral scapes kept in a postharvest room 
with a temperature of $20 \pm 2{ }^{\circ} \mathrm{C}$ and relative humidity of $80 \pm$ $3 \%$ showed longevity of $14.9 \pm 1.5$ days, and it corresponds to the stage IV of the senescence scale (Figure 1; and 2). Postharvest longevity of this bromeliad is an advantageous feature for the cut flowers market. In species of largevolume in the world trade, the vase-life is only 6.5 days for Rose cv. Carola (WU et al., 2016), 8.9 days for Carnation cv. White Natila (BEGRI et al., 2014), and 9.0 days for Alstroemeria (BABARABIE et al., 2014). Postharvest longevity is considered a fundamental prerequisite for commercialization of cut flowers (RAFDI et al., 2014). The long period of longevity of $V$. incurvata floral scapes, make it a viable alternative to include as a new flower to use as cut flower both locally and internationally.

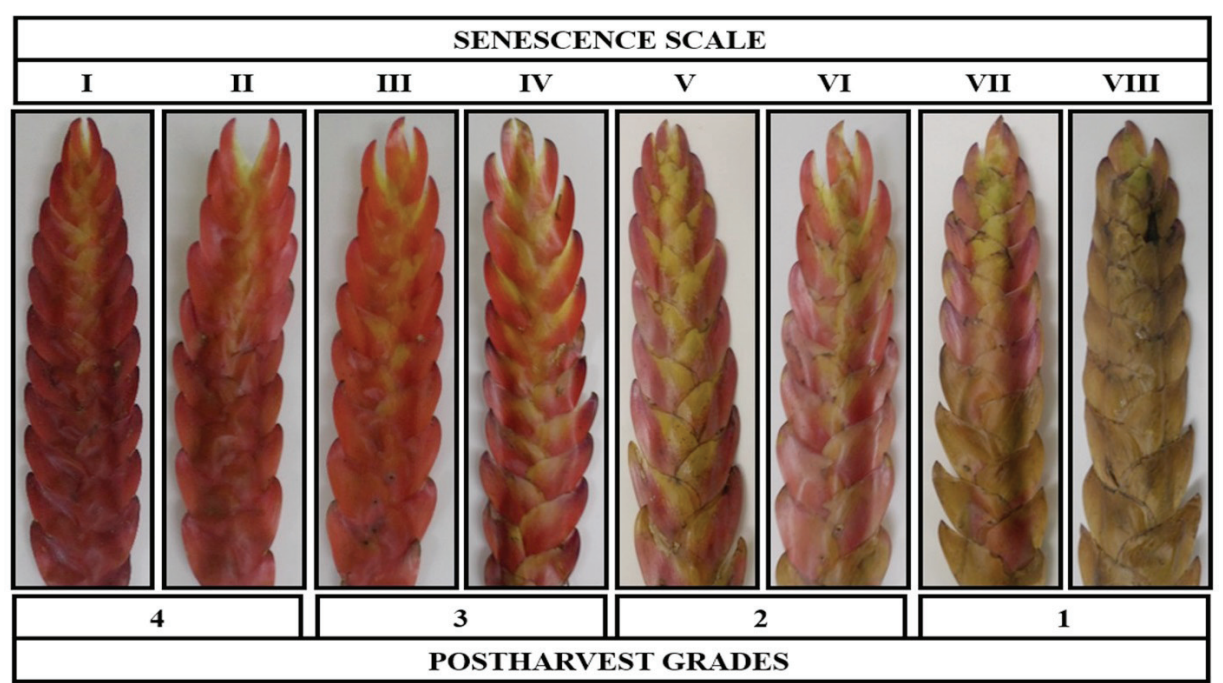

Figure 1. Senescence scale and grades attributed to $V$. incurvata floral scapes in cut flowers postharvest.

However, the longevity is not the only requirement to consider a plant liable for use as a cut flower. Aesthetic and physiological characteristics are also considered with great importance in the establishment and launch of new products in floriculture market (VABRIT, 2002; REID and JIANG, 2012).
Evaluation criteria are a tool for the standardization and control of ornamental plants postharvest quality. Postharvest evaluation criteria selected for $V$. incurvata floral scapes were color, brightness, turgidity, presence of injuries, stiffness and commercial perception (Table 1; Figure 2). Each criterion was scored by grades (1: minimum - 4: maximum) in relation to its technical specification, according to Table 1.

Table 1. Criteria, grades and technical specifications for postharvest evaluation of $V$. incurvata floral scapes.

\begin{tabular}{|c|c|c|c|c|}
\hline Criterion & Grade 4 & Grade 3 & Grade 2 & Grade 1 \\
\hline Color inflorescence & colorful/strong & medium-colored & discolored & very discolored \\
\hline $\begin{array}{l}\text { Brightness } \\
\text { inflorescence }\end{array}$ & $\begin{array}{l}\text { with brightness and } \\
\text { no dryness at the } \\
\text { bracts ends }\end{array}$ & $\begin{array}{l}\text { with brightness and light } \\
\text { dryness at the bracts ends }\end{array}$ & $\begin{array}{l}\text { with light brightness } \\
\text { and dryness at the bracts } \\
\text { ends }\end{array}$ & $\begin{array}{c}\text { with no brightness } \\
\text { and dryness at the } \\
\text { bracts ends }\end{array}$ \\
\hline Turgidity & turgid & averagely turgid & slightly turgid & wilted \\
\hline $\begin{array}{c}\text { Presence of injuries in } \\
\text { the floral scape }\end{array}$ & $<5 \%$ with injury & $<10 \%$ with injury & $<30 \%$ with injury & $>30 \%$ with injury \\
\hline $\begin{array}{c}\text { Stiffness of the floral } \\
\text { scape }\end{array}$ & hard & moderately hard & slightly flexible & flexible \\
\hline $\begin{array}{l}\text { Commercial } \\
\text { perception }\end{array}$ & excellent & good & regular & bad \\
\hline
\end{tabular}

*Each criterion was scored by grades (1: minimum - 4: maximum). 
The scale developed in this study favored the measurement of the different postharvest evaluation criteria (Figure 2). According to Cuquel and Polack (2012) decreasing scales are the most adequate in assessing of quality losses, since it is instinctive for human beings to assume that the best products are equivalent to higher scores.

After harvesting, $V$. incurvata floral scapes received grade 4 in all postharvest evaluation criteria (Figure 2). As expected, from the first days until the end of the postharvest period the floral scapes lost their ideal marketing characteristics, registering decreasing grades until reaching grade 1 (Figures 1 and 2). Color, brightness, turgidity, and commercial perception of floral scapes were maintained with grade 3 up to 14 days of vase-life (Figures 1 and 2). In species such as Oncidium baueri (Orchidaceae) and Chrysanthemum morifolium cv. Dragon, even with the use of preservative solutions to maintenance postharvest quality of floral stems, was between 3 and 8 days of vaselife (SPRICIGO et al., 2010; FAVETTA et al., 2016). The presence of injuries in floral scapes showed grade 3 up to the first seven days of vase-life. The stiffness of floral scapes was recorded with grade 4 (hard) throughout all the postharvest period (Figures 1 and 2). This behavior was also observed during the vase-life of Heliconia spp. floral stems (BEZERRA et al., 2008).

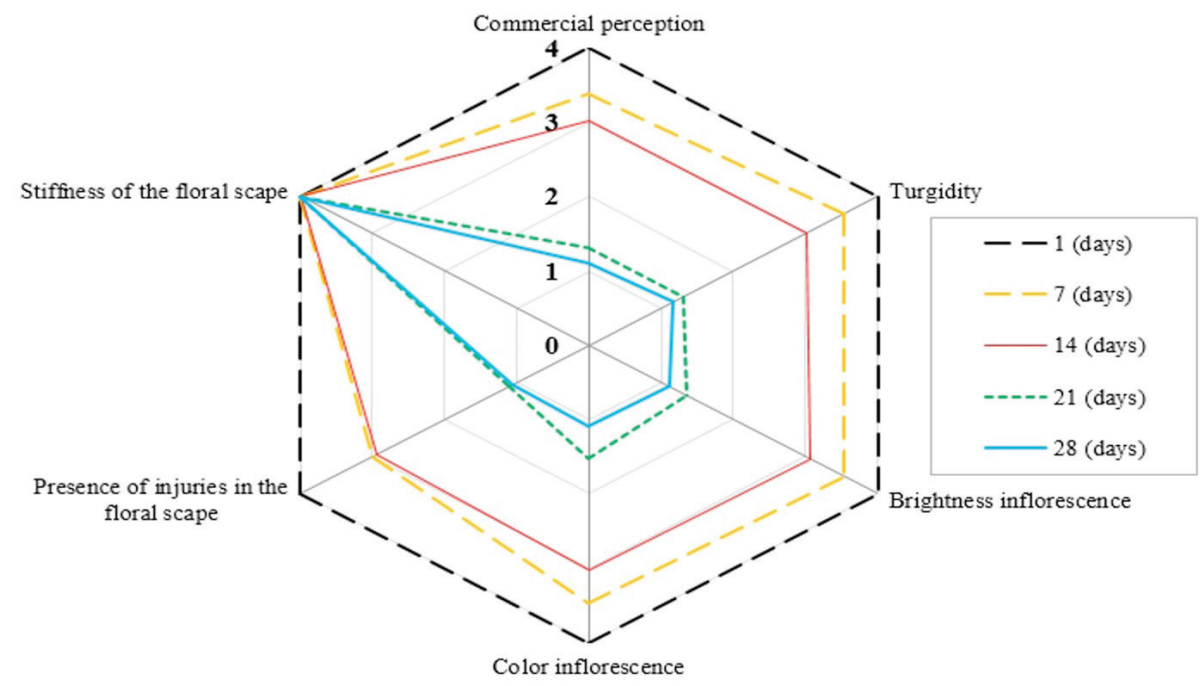

Figure 2. Postharvest evaluation criteria and grades attributed to $V$. incurvata floral scapes. The values are averages of thirty replications, each one conformed by a floral scape. Each floral scape was evaluated with a rating scale by six evaluators.

During the postharvest period, physiological changes were also observed in the $V$. incurvata floral scapes. Relative fresh weight (RFW) decreased during the vase-life of $V$. incurvata floral scapes (Figure 3A). The greatest relative fresh weight loss $(22.58 \%)$ of floral scapes was observed in the first seven days of vase-life. Floral scapes registered losses of $34.61 \%$ of relative fresh weight during vaselife $(14.9 \pm 1.5$ days) (Figure 3A). According to Morales (2011), the decrease of the fresh weight in cut flowers, is a normal response, due to the increase of ethylene production after the harvest, and consequently, the activation of the senescence process.

Quality loss postharvest in fresh products, specifically in cut flowers, is related to the process of dehydration produced by the transpiration (SILVA, 2003). The water balance is a determining factor in the vase-life of cut flowers (GONZAGA et al., 2001). In this study, water uptake (WU) was found to increase during vase-life of $V$. incurvata floral scapes (Figure 3B). The highest water uptake of $3.70 \mathrm{~g} \mathrm{scape}^{-1}$ day $^{-1}$ of floral scapes was observed in the first seven days of vase-life. Total water uptake of floral scapes during vase-life $(14.9 \pm 1.5$ days $)$ was $6.91 \mathrm{~g} \mathrm{scape}^{-1}$ day $^{-1}$ (Figure 3B). However, the highest water loss (7.18 g scape $^{-1}$ day $^{-1}$ ) of floral scapes was observed in the first seven days of vase-life (Figure 3B). Total water loss of the floral scapes during vase-life $(14.9 \pm 1.5$ days $)$ was $7.38 \mathrm{~g} \mathrm{scape}^{-1}$ day $^{-1}$ (Figure 3B). 

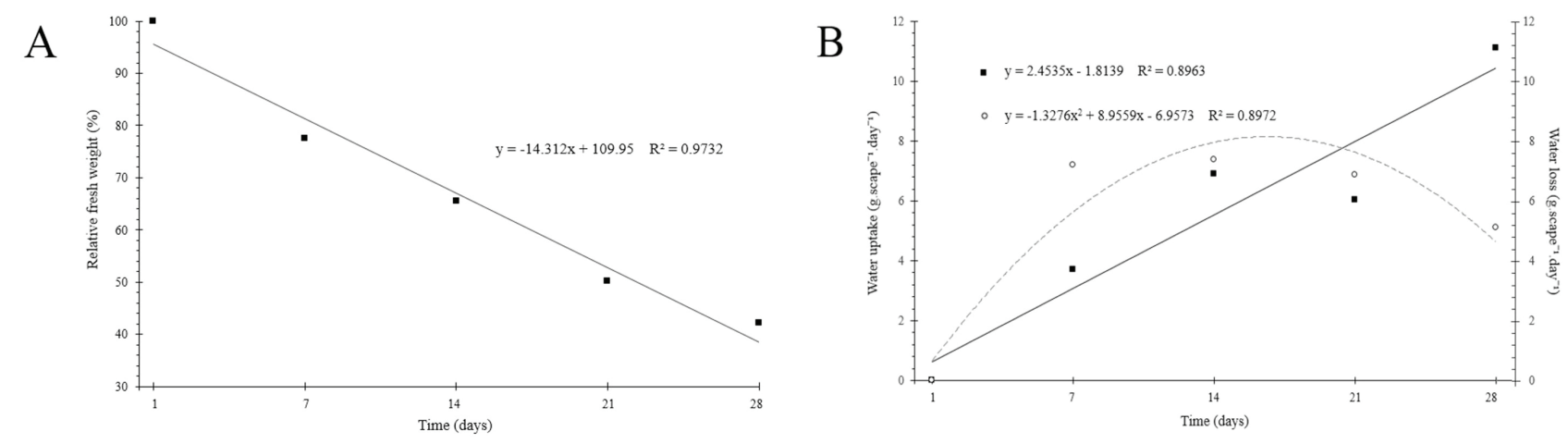

Figure 3. Relative fresh weight - RFW (A), water uptake - WU (ם) and water loss - WL (O)(B) of $V$. incurvata floral scapes. The values are averages of thirty replications, each one conformed by a floral scape.

The bracts color of $V$. incurvata measured in intensity $\left(\mathrm{C}^{*}=\right.$ chromaticity $)$, hue $\left(\mathrm{H}^{\circ}=\right.$ Hue angle $)$ and luminosity $\left(\mathrm{L}^{*}\right)$ showed variations during the postharvest period of the floral scapes (Figure 4).

Color intensity of the bracts decreased during all the postharvest period of $V$. incurvata floral scapes, which corresponds to the lower color vivacity (Figure 4A and 1). Orange-colored bracts with chromaticity values of 21.91 to 30.13 were observed in floral scapes during the vase-life (14.9 \pm 1.5 days) (Figure 4A).

Hue angle of the bracts had an upward behavior during all the postharvest period of floral scapes, which corresponds to the highest color degradation, changing from red-orange to yellow-orange shades (Figures 4B and 1). Bracts with red-orange shades with a Hue angle values between 40.73 and 45.69 were observed during the vase-life $(14.9 \pm 1.5$ days $)$ of the floral scapes (Figure 4A).

Bracts color luminosity showed a constant behavior during the postharvest period of $V$. incurvata floral scapes (Figure 4C). Luminosity values from 37.75 to 38.38 were observed during floral scapes vase-life (14.9 \pm 1.5 days) (Figure 4C). Results of the bracts color chromaticity, Hue angle and luminosity showed that $V$. incurvata has a very similar behavior of postharvest life in relation to other cut flowers, probably associated to the anthocyanins and chlorophyll content present in the flowers (SKUTNIK et al., 2004; MACNISH et al., 2010).
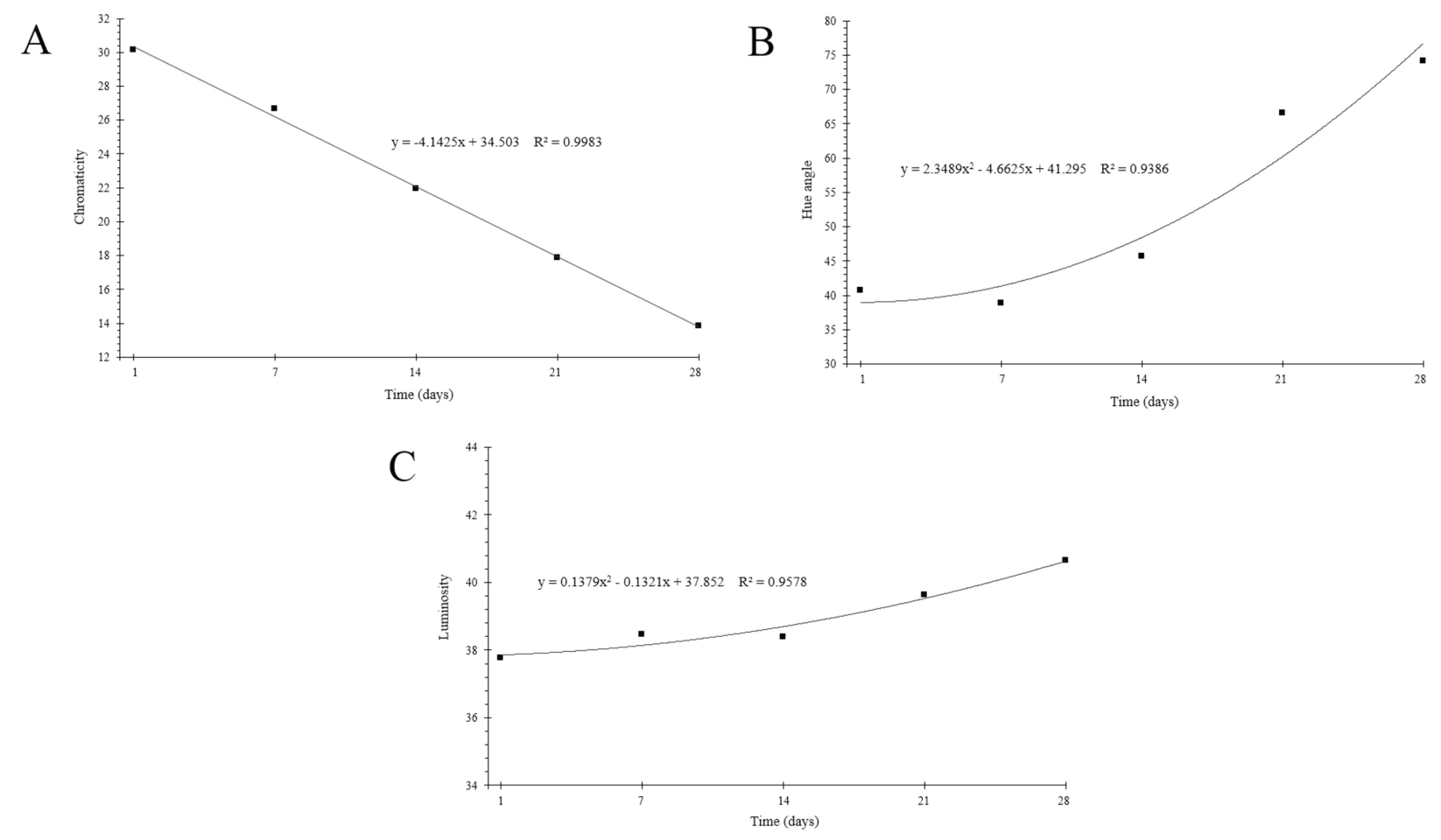

Figure 4. Chromaticity (A), hue angle (B) and luminosity (C) of $V$. incurvata floral scapes. The values are averages of thirty replications, each one conformed by a floral scape. 
Floral scapes showed symptoms of accelerated senescence after the $14.9 \pm 1.5$ days of vase-life (Figures 1,3 and 4). This final period of floral scapes senescence was characterized by recording decreasing percentages of relative fresh weight (RFW) and higher water uptake (WU) (Figure 3). Additionally, the bracts initiated an accelerated drying, darkening and discoloration process, corresponding to the stages V to VIII in the senescence scale (Figures 4 and 1). According to Van Doorn (1997), the symptoms of accelerated senescence in cut flowers are related to the water deficit, which causes turgidity reduction and discoloration of flowers and/or other organs.

\section{CONCLUSIONS}

Floral scapes of $V$. incurvata can have ornamental use as cut flower, achieving an average vase-life of $14.9 \pm 1.5$ days.

Quantitative and qualitative characteristics such as color $\left(\mathrm{L}^{*}, \mathrm{C}^{*}, \mathrm{H}^{\circ}\right)$, brightness, turgidity, stiffness, presence of injuries, relative fresh weight, water uptake and loss can be indicated as evaluation criteria in postharvest of $V$. incurvata floral scapes.

\section{ACKNOWLEDGMENTS}

This work was supported by the Post-graduate Program in Agronomy/Plants Production of Federal University of Paraná (UFPR). The first author thanks the Organization of American States (OAS) through the OAS-GCUB Program (Coimbra Group of Brazilian Universities) for granting doctoral fellowship.

\section{AUTHORS CONTRIBUTIONS}

E.P.: Creation of the idea, literature review, takes the photos, laboratory analysis, data collection, obtaining of funds and materials, preparation of the manuscript. F.C.: Creation of the idea, laboratory analysis, data collection, obtaining of funds and materials, preparation of the manuscript. R.N.: Creation of the idea, laboratory analysis, data collection, obtaining of funds and materials, preparation of the manuscript.

\section{REFERENCES}

ALAEY, M.; BABALAR, M.; NADERI, R.; KAFI, M. Effect of pre- and postharvest salicylic acid treatment on physio-chemical attributes in relation to vase-life of rose cut flowers. Postharvest Biology and Technology, v.61, p.91-94, 2011. DOI: <http://dx.doi.org/10.1016/j. postharvbio.2011.02.002>

BABARABIE, M.; ZAREIE, H.; VARASTEH, F. The effect of cola on postharvest physiological characteristics of cut Alstroemeria. Journal of Ornamental Plants, v.4, n.3, p.169-174, 2014.
BEGRI, F.; HADAVI, E.; NABIGOL, A. Positive interaction of ethanol with malic acid in postharvest physiology of cut spray carnation 'White Natila'. Journal of Horticultural Research, v. 22, n.2, p.19-30, 2014. DOI: $<$ http://dx.doi.org/10.2478/johr-2014-0018>

BEZERRA, G.; VERONA, A.; MOTTA, R.; LOGES, V.; COSTA, A. Chilling symptoms in Heliconia spp. Revista Brasileira de Horticultura Ornamental, v.14, n.2, p.193196, 2008. DOI: <http://dx.doi.org/10.14295/rbho.v14i2.290>

BOUMAZA, R.; DEMOTES-MAINARD, S.; HUCHETHELIER, L.; GUERIN, V. Visual characterization of the esthetic quality of the rosebush. Journal of Sensory Studies, v.24, p.774-796, 2009. DOI: <http://dx.doi. org/10.1111/j.1745-459X.2009.00238.x>

CUQUEL, F.; POLACK, S. Shelf-Life of Anthurium cut flowers: evaluation criteria. Acta Horticulturae, v.934, p.435-439, 2012. DOI: <http://dx.doi.org/10.17660/ ActaHortic.2012.934.57>

FAVETTA, V.; COLOMBO, R.; FARIA, R. Floral stems longevity of Oncidium baueri kept in preservative solutions. Comunicata Scientiae, v.7, n.2, p.209-213, 2016. DOI: $<$ http://dx.doi.org/10.14295/cs.v7i2.857>

GONZAGA, A.; MOREIRA, L.; LONARDONI, F.; FARIA, R. Sunflower postharvest longevity affected by silver nitrate and sucrose treatments. Revista Brasileira de Horticultura Ornamental, v.7, n.1, p.73-77, 2001. DOI: $<\mathrm{http} / / /$ dx.doi.org/10.14295/rbho.v7i1.81>

HE, S.; JOYCE, D.C.; IRVING, D.E. Competition for water between inflorescences and leaves in cut flowering stems of Grevillea 'Crimson Yul-lo'. Journal of Horticultural Science and Biotechnology, v.81, p.891-897, 2006.

HEIDEN. G.; BARBIERI, R.L.; STUMPF, E.R.T. Considerations about the use of ornamental native plants. Revista Brasileira de Horticultura Ornamental, v.12, n.1, p.2-7, 2006. DOI: <http://dx.doi.org/10.14295/rbho. v12i1.60>

JUNQUEIRA, A.H.; PEETZ, M. Socioeconomic overview of floriculture in Brazil. Revista Brasileira de Horticultura Ornamental, v.17, n.2, p.101-108, 2011. DOI: <http://dx.doi.org/10.14295/rbho.v17i2.704>

MACNISH, A.; JIANG, C.; NEGRE-ZAKHAROV, F.; REID, M.S. Physiological and molecular changes during opening and senescence of Nicotiana mutabilis flowers. Plant Science, v.179, n.3, p.267-272, 2010. DOI: <http:// dx.doi.org/10.1016/j.plantsci.2010.05.011>

MARTINELLI, G.; VIEIRA, C.M.; GONZALEZ, M.; LEITMAN, P.; PIRATININGA, A.; COSTA, A.F.; FORZZA, R.C. Bromeliaceae da Mata Atlântica Brasileira: lista de espécies, distribuição e conservação. Rodriguésia, v.59, n.1, p.209-258, 2008. 
MORALES, F. Cut flowers postharvest and environment. Idesia, v.29, n.3, p.125-130, 2011. DOI: <http://dx.doi. org/10.4067/S0718-34292011000300019>

NEGRELLE, R.; ANACLETO, A. Bromeliads wild harvesting in State of Paraná. Ciência Rural, v.42, n.6, p.981-986, 2012. DOI: <http://dx.doi.org/10.1590/S0103$84782012000600005>$

RAFDI, H.H.M.; JOYCE, D.C.; LISLEB, A.; LIB, X.; IRVINGD, D.E.; GUPTA, M. A retrospective study of vase-life determinants for cut Acacia holosericea foliage. Scientia Horticulturae, v.180, p.254-261, 2014. DOI: $<$ http://dx.doi.org/10.1016/j.scienta.2014.10.020>

RANI, P.; SINGH, N. Senescence and postharvest studies of cut flowers: a critical review. Tropical Agriculture Science, v.37, n.2, p.159-201, 2014.

REID, M.; JIANG, C. Postharvest biology and technology of cut flowers and potted plants. JANEK, J. Horticultural reviews. Hoboken: John Wiley \& Sons, 2012. pp.1-54.

REITZ, R. Bromeliáceas e a malária - Bromélia endêmica. Itajaí: Flora Ilustrada Catarinense, 1983. 608p.

RUBEL, F.; KOTTEK, M. Observed and projected climate shifts 1901-2100 depicted by world maps of the Köppen-Geiger climate classification. Meteorologische Zeitschrift, v.19, n.2, p.135-141, 2010. DOI: <http:// dx.doi.org/10.1127/0941-2948/2010/0430>

SILVA, J. The cut flower: postharvest considerations. Journal of Biological Sciences, v.3, n.4, p.406-442, 2003.
SKUTNIK, E.; RABIZA-ŚWIDER, J.; WACHOWICZ, M.; ŁUKASZEWSKA, A. Senescence of cut leaves of Zantedeschia aethiopica and Z. elliottiana. Part I. Chlorophyll degradation. Acta Scientiarum Polonorum. Hortorum Cultus, v.3, n.2, p.57-65, 2004.

SMITH, L.B.; TILL, W. Bromeliaceae. KUBITZKI, K. The families and genera of vascular plants. Berlin: Springer, 1998. p.74-99.

SPRICIGO, P.; MATTIUZ, B.; PIETRO, J.; MATTIUZ, C.; OLIVEIRA, M. Chrysanthemum morifolium cv. Dragon postharvest maintenance solutions. Ciência e Agrotecnologia, v.34, n.5, p.1238-1244, 2010. DOI: $<$ http://dx.doi.org/10.1590/S1413-70542010000500023>

VABRIT, S. Morphological aspects for selecting new bedding plants. Acta Horticulturae, v.572, p.67-74, 2002. DOI: <http://dx.doi.org/10.17660/ActaHortic.2002.572.7>

VAN DOORN, W.G. Water relations of cut flowers. Horticultural Reviews, v.18, p.1-85, 1997.

WU, L.Y.; XIAO, H.; ZHAO, W.J.; SUN, P.; LIN, J.K. Effect of green tea extract powder on the vase-life of freshcut rose (Rosa hybrida L.) 'Carola' stems. The Journal of Horticultural Science and Biotechnology, v.91, n.3, p.279-284, 2016. DOI: <http://dx.doi.org/10.1080/146203 16.2016.1155316>

YAMADA, K.; TAKATSU, Y.; MANABE, T.; KASUMI, M.; MARUBASHI, W. Suppressive effect of trehalose on apoptotic cell death leading to petal senescence in ethylene-insensitive flowers of gladiolus. Scientia Horticulturae, v.164, n.2, p.213-221, 2003. DOI: <http:// dx.doi.org/10.1016/S0168-9452(02)00403-X> 